\title{
Polimerler-Kil Nanokompozitlerinde Kullanılan Bazı Yüzey Analiz Yöntemleri
}

\author{
Nevin ÇANKAYA*1, Özlem SÖKMEN1 \\ ${ }^{1}$ Uşak Üniversitesi, Fen Edebiyat Fakültesi, Kimya Bölümü, 64000 Uşak, Türkiye
}

(Alınış / Received: 2.7.2020, Kabul / Accepted: 16.01.2021)

Anahtar Kelimeler
FTIR,
XRD,
SEM,
TEM,
AFM,
Yüzey Analiz.

\section{Anahtar Kelimeler}

SEM,

AFM,

Yüzey Analiz.

\begin{abstract}
Özet: Polimer içerikli malzemeler, doğal ya da sentetik yapıdaki polimerler ile hazırlanan, nanometre boyutunda analiz edilebilen matris sistemlerdir. Nanoölçek seviyesinde yapılar içeren malzemelerin özellikleri makroskopik ölçekten tamamen farklıdır. Nano boyuttaki malzemenin iletim özellikleri (momentum, enerji ve kütle), optik, elektronik, manyetik ve kimyasal özellikleri değişir. Polimerlere kil katkısı ile polimer/kil nanokompozitler elde edilir ve çeşitli spektroskopik yöntemler kullanılarak polimer/kil nanokompozitlerin termal, mekanik ve yüzey karakterizasyonu yapılabilmektedir. Bu çalıșmada, yüzey analiz metotlarında kullanılan İnfrared Spektroskopisi (FTIR), X- Işınları Kırınım Yöntemi (XRD), Taramalı Elektron Mikroskobu (SEM), Geçirimli Elektron Mikroskobu (TEM), Atomik Kuvvet Mikroskobu (AFM) hakkında bilgi verilmiştir.
\end{abstract}

\section{Some Surface Analysis Methods Used in Polymers-Clay Nanocomposites}

\section{Keywords}

FTIR,

XRD,

SEM,

TEM,

AFM,

Surface analysis.

\begin{abstract}
Polymer-containing materials, prepared with polymers of natural or synthetic structure, are matrix systems that can be analyzed in nanometer size. The properties of materials containing structures at the nano-scale level are completely different from the macroscopic scale. Transmission properties of material in nanoscale size (momentum, energy, and mass), optical, electronic, magnetic and chemical properties change. Polymer clay nanocomposites are obtained with clay additive to polymers and can be made thermal, mechanical and surface characterization of polymer / clay nanocomposites with various spectroscopic methods. In this study, Infrared Spectroscopy (FTIR), X-Ray Diffraction Method (XRD), Scanning Electron Microscopy (SEM), Transmission Electron Microscopy (TEM), Atomic Force Microscopy (AFM) and which are the most used techniques in surface analysis of polymer / clay nanocomposites are given.
\end{abstract}

\section{Giriş}

Doğal ve sentetik polimerler birçok uygulama alanına sahip materyallerdir [1]. Polimerlere kil ilave edilmesiyle kompozitler elde edilir ve bu kompozitlerin yapılarının aydınlatılmasında geleneksel spektroskopik yöntemler kullanılır [2]. Bir materyalin yüzey tabakalarının kimyasal ve fiziksel özelliklerinin tanımlanmasına yüzey analizi denir. Katıların fiziksel veya kimyasal değișimlere vereceği tepkimeler, malzemenin yüzeyi ile ilgili olduğundan yüzey analiz yöntemleri önem kazanmaktadır [3].
Kimyanın, malzeme biliminin ve biyolojinin birçok çalışma alanında katı yüzeylerin fiziksel özelliği ile ilgili ayrıntılı bilgi alabilmek için optik mikroskobisi kullanılır. Bu tekniklerde enerji yüklü tanecikler örnek yüzeyine yönlendirilir ve yüzeyden yayılan emisyon incelenir. Maddenin yüzeyi X-ışınları, yüksek enerjili elektronlar, fotonlar veya iyonlar ile etkileștirilir. Yüzeyin etkileşimi sonucunda yayılan ışınlara ikincil demet denir. İkincil demetler incelendiğinde materyalin yüzeyi hakkında fiziksel ve kimyasal bilgiler elde edilir [4]. Mikroskobik metotlar yüksek enerjili elektronların çok küçük nesneleri belirlemek 
amacıyla kullanıldığı cihazlardır. Bu mikroskobik yöntemler ile maddeyi meydana getiren parçaların şekil ve boyutunu (morfoloji), maddeyi meydana getiren parçaları yüzey özelliklerini, biçimi, sertliği, 1

gibi yüzey özelliklerinin nasıl göründüğüne dair özellikleri (topografi), nesneyi oluşturan atomların nasıl düzenlendiğini (kristalografi) gösteren bilgiler elde edilir [5]. Malzeme yüzeylerinin fiziksel ve kimyasal özelliklerinin belirlenmesinde yaygın olarak kullanılan yüzey analiz yöntemleri spektroskopik ve mikroskobik yüzey analiz yöntemleri olarak iki kısımda incelenir. Tablo 1'de spektroskopik ve mikroskobik yüzey analiz yöntemleri verilmiştir $[4,6]$.

Tablo 1. Spektroskopik ve mikroskobik yüzey analiz yöntemleri

\begin{tabular}{|l|}
\hline 1. Spektroskobik yüzey analiz yöntemleri: \\
1a) X-Işınları Floresans Spektroskopisi (XRF) \\
1b) X-Işınları Difraksiyonu (XRD) \\
1c) X-Işınları Fotoelektron Spektroskopisi (XPS) \\
1d) Auger Elektron Spektroskopisi (AES) \\
1e) Ultraviyole Fotoelektron Spektroskopisi (UPES) \\
1f) İkincil İyon Kütle Spektroskopisi (SIMS) \\
\hline 2. Mikroskobik yüzey analiz yöntemleri: \\
2.1. Taramalı Prop Mikroskopisi (SPM) \\
2.1.a) Taramalı Tünelleme Mikroskopisi (STM) \\
2.1.b) Atomik Kuvvet Mikroskopisi (AFM) \\
2.2. Elektron Mikroskopisi (EM) \\
2.2.a) Taramalı Elektron Mikroskopisi (SEM) \\
2.2.b) Geçirimli Elektron Mikroskopisi (TEM) \\
\hline
\end{tabular}

Tablo 1' de verilen spektroskopik ve mikroskobik yüzey analizlerinin dışında infrared spektroskopisi (FTIR) yüzeyde bulunan fonksiyonel grupları karakterize etmek amacıyla kullanılmaktadır [7].

\section{Infrared Spektroskopisi (FTIR)}

FTIR, maddenin infrared ışınlarını absorplaması veya saçması üzerine kurulmuş olan bir spektroskopi dalıdır. Homonükleer moleküller (N2, 02 ve Cl2 gibi) hariç bütün moleküller infrared ışınlarını absorplar. Organik molekülün yapısında bulunan fonksiyonel gruplarda bulunan bağ tipine ve atom cinsine göre enerjinin soğurulması sonucu titreşimler gerçekleşir. Moleküller değişik tiplerde titreşim hareketleri gösterebilirler. $\mathrm{Bu}$ titreşimler ileri geri eğilme ve bükülme titreşimleridir [8].

Infrared spektrometresi bir IR ışın kaynağından çıkan ışınların örnek içinden geçirilmesi ve örnekten çıkan ışını referanstan gelen ışını karşılaştırma ilkesiyle çalışır. Spektrometre sonuçları absorbans veya geçirgenliğe karşı dalga sayısını gösteren spektrumlar olarak elde edilir. Tablo 2'de polimer kil nanokompozitlerinde kullanılan polimer ve kile ait fonksiyonel gruplar verilmiştir [9].
Tablo 2. Polimer kil nanokompozitlerinde yararlanılan infrared fonksiyonel gruplar

\begin{tabular}{|c|c|c|}
\hline \multicolumn{2}{|c|}{ FONKSIYYONEL GRUP } & \multirow{2}{*}{$\begin{array}{l}\text { TİTREŞİM (cm-1) } \\
\text { Gerilme, 2950-2850 }\end{array}$} \\
\hline \multirow{13}{*}{ POLİMER } & Alkil C-H & \\
\hline & Alkenil $=\mathrm{C}-\mathrm{H}$ & Gerilme, 3100-3000 \\
\hline & & Ĕ̆ilme 1480-1350 \\
\hline & Alkinil C-H & Gerilme ,3300 \\
\hline & Aromatik C-H & Gerilme 3030 \\
\hline & Aromatik C-H & Eğilme, 900-680 \\
\hline & Alkenil $\mathrm{C}=\mathrm{C}$ & Gerilme, $1680-1620$ \\
\hline & Amit $\mathrm{C}=0$ & Gerilme,1690-1630 \\
\hline & Ester $\mathrm{C}=\mathrm{O}$ & Gerilme, 1750-1735 \\
\hline & $\mathrm{C}=\mathrm{N}$ & Gerilme,1490,1420 \\
\hline & Alkol fenol O-H & Gerilme, 3550-3200 \\
\hline & $\begin{array}{l}\text { Karboksilik asit O- } \\
\mathrm{H}\end{array}$ & Gerilme, 3000-2500 \\
\hline & Amit N-H & Gerilme, 3700-3500 \\
\hline \multirow{8}{*}{ KİL } & Silan Si-H & Gerilme, 2100-2360 \\
\hline & Si-OR & Gerilme, 1110-1000 \\
\hline & $\mathrm{Si}-\mathrm{O}-\mathrm{Si}$ & Gerilme, 1150-900 \\
\hline & & $775-600$ \\
\hline & $\mathrm{Si}-\mathrm{CH}_{3}$ & Gerilme, 1250 \\
\hline & $\mathrm{H}-\mathrm{O}-\mathrm{H}$ & Eğilme, 1645-1620 \\
\hline & $\mathrm{Al}-\mathrm{O}$ & Gerilme, 550 \\
\hline & Al-O-H & Eğilme, 855 \\
\hline
\end{tabular}

Halloysit, montmorillonit ya da organokil gibi çeşitli kil gruplarındaki ve polimerdeki fonksiyonel grupların yerleri Tablo 2'de verilen fonksiyonel gruplara bakılarak tespit edilir. Polimerin ilk hali ile kompozit oluştuktan sonraki FTIR spektrumu alınarak kompozitin yapısı aydınlatılır. Kompozitte bulunan kil tabakaları düzenli olarak sıralanabildiği gibi düzensiz bir yapıda oluşturabilir. Polimer zincirleri kil tabakaları içerisinde her iki pozisyonda da bulunabilir. Bu durum kompozitin yapısını anlamak için yeterli bir teknik olmayıp sadece fonksiyonel grupların varlığı hakkında bilgi verebilir [10].

Hidrojel ve hidrojel/kil kompozitlerinde FTIR tekniği; polimer yapıyı oluşturan monomerlerin, destek malzeme olan kil mineralleriyle nasıl etkileştiğinin aydınlatılması amacıyla kullanılmaktadır. Polimer zincir üzerinde bulunan hidrofobik veya hidrofilik yapıların kil minerali yüzey veya tabaka arasında bulunan aktif merkezlerle, tabaka içi anyon ya da katyonlarla veya değiștirilebilen iyonlarla etkileşimlerinde FTIR spektrumu kullanılarak yapıların aydınlatılması sağlanır. Saf polimerin veya destek malzemesi olan kilin spektrumlarının elde edilen kompozit ile karşılaştırılması ve yorumlanması 
ve kompozit malzeme sentezlenirken olușan etkileşimler hakkında bilgi edinilir $[11,12]$.

Aranda ve Hitzky (1999) çalışmalarında Polietilenoksit/NH4+ kil nanokompoziti $1 \mathrm{M} \mathrm{NaClO4}$ çözeltisi ile muamele edildikten sonra FTIR spektrumu alınmış ve amonyum iyonları ile sodyum iyonlarının yer değiştirmiş olduğu FTIR spektrumu ile kanıtlanmıştır [13].

Ekici vd., (2005) çalışmalarında, Poliakrilamid/Sepiyolit kompozit hidrojellerini hazırlamışlar ve bu kompozitin adsorpsiyon özelliklerini incelemişlerdir. Poliakrilamid/Sepiyolit kompozit hidrojellerine ait FTIR spektrumu incelendiğinde akrilamide ait olan pik şiddetlerinin arttığı ve kompozit oluşumunda yeni pik gözlemlenmediği için sepiyolitin aktif destek maddesi olarak davrandığı belirtilmiştir. Çalışmanın BB-9 boya adsorpsiyonu kısmında Si-OH gruplarının -OH titreşimlerine ait bandın şiddetinin azalması boyadaki anyonik gruplarıla sepiyolit mineralinin özellikle köşelerindeki silanol gruplarıyla etkileştiği tespit edilmiştir [14]. Şekil 1'de Poliakrilamit/Sepiyolit ve BB9 boyası adsorbe olmuş nanokompozitinin FTIR spektrumu verilmiştir.

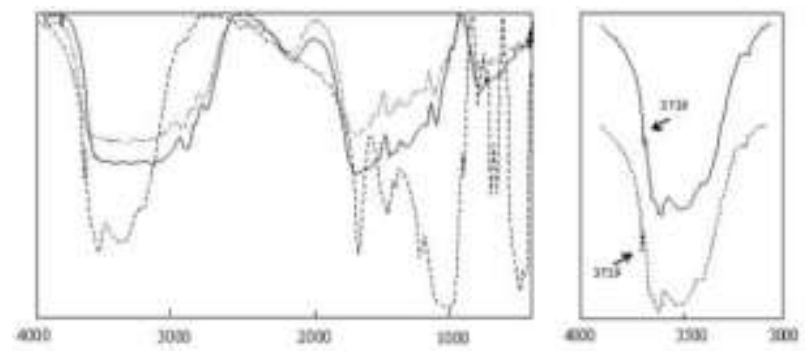

Şekil1. Poliakrilamit/Sepiyolit ve BB9 boyası adsorbe olmuş kompozitinin FTIR spektrumu

Wang vd., (2015) çalışmalarında, Poliakrilikasit (PAA)/Akrilamit (AM) ve PAA/AM/HNT (Halloysit) kompozitlerini sentezlemişlerdir. Kompozitte kullanılan HNT kilinin FTIR spektrumunda, 3695 ve 3624 cm-1 görülen pikler hidroksil gruplarının gerilme titreşimlerine, $1030-910 \mathrm{~cm}-1$ de görülen pik Al-OH bükülme titreşimine ve $693 \mathrm{~cm}-1$ HNT kilindeki Si-O grubuna, $535 \mathrm{~cm}-1$ 'deki pik Al-O-Si deformasyon titreşimlerine ait olduğu tespit edilmiştir. PAA/AM kopolimerindeki AM'de ait olan N-H titreşimi 3440 $\mathrm{cm}-1, \mathrm{COOH}$ grubundaki $\mathrm{C}=0$ gerilme titreşimi 1550 cm-1 de, $\mathrm{CH} 2$ ve $\mathrm{CH} 3$ gruplarının deformasyon titreşimleri $1410 \mathrm{~cm}-1$ 'de görülmüștür. CH2'nin karakteristik absorpsiyon pikleri $2930 \mathrm{~cm}-1$ de CH3'ün karakteristik piki ise $2850 \mathrm{~cm}-1$ de görülmektedir. HNT kil yüzeyindeki hidroksil gruplariyla, monomerdeki $-\mathrm{C}=\mathrm{C}-$ grubundaki etkileşimden, kompozitteki HNT kilinde gözlenen 3695 cm-1 ve 3624 cm-1 de görülen pikler kompozit spektrumunda kaybolmuştur. Kompozit ve HNT kilinin FTIR spektrumu Şekil 2'de verilmiştir [15].

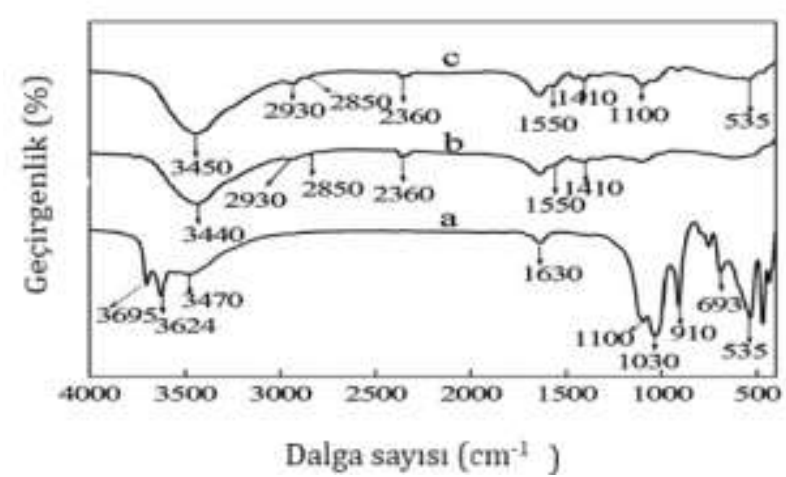

Şekil 2. a) Halloysit (HNT) kilinin FTIR spektrumu b) Poliakrilikasit(PAA)/Akrilamit(AM) kompozitinin FTIR spektrumu c) PAA/AM/HNT kompozitinin FTIR spektrumu

Li vd. (2005) çalışmalarında, \%10 Attapulgit kili içeren nişasta-graft-poli(akrilamit)/attapulgit süperadsorban kompozitini sentezlemişler ve bu kompozitin FTIR spektrumu Şekil 3c'de verilmiştir. Şekil 3a'da attapulgit kilinin, Şekil 3b'de ise çapraz bağlı nişasta-graft-poli(akrilamit) polimerinin FTIR spektrumu verilmiștir. 3443 cm-1'deki pik kompozitteki NH2 gruplarına, 2930 cm-1'deki pik nişasta ve akrilat birimlerindeki $-\mathrm{C}-\mathrm{H}$ titreşimine, $1673 \mathrm{~cm}-1$ pik (-CONH2) grubundaki $\mathrm{C}=0$ titreşimine, $1585 \mathrm{~cm}-1$ 'deki pik (-COONa) grubundaki $\mathrm{C}=0,1079$ ve $1172 \mathrm{~cm}-1$ 'deki pik nişastada yer alan $\mathrm{C}=0$ titreșimine, $1022 \mathrm{~cm}-1$ 'deki pik ise attapulgit kilinin gerilme titreşimine ait olduğu FTIR spektrumundan anlaşımıştır. Aşı kopolimerizasyondaki $\mathrm{OH}$ grupları ile attapulgit kili arasında reaksiyon olduğu tespit edilmiştir. Şekil 3a ve 3c'nin FTIR spektrumu karşılaştırıldığında, 3621 ve 3549 cm-1 attapulgit kiline ait olan $-\mathrm{OH}$ piklerinin reaksiyondan sonra görülmediği tespit edilmiştir (Şekil 3c). Çapraz bağlı polimerin FTIR spektrumu ile kompozitin spektrumu karşılaştırılarak kompozitin oluşumu hakkında bilgi edinilmiştir [16].

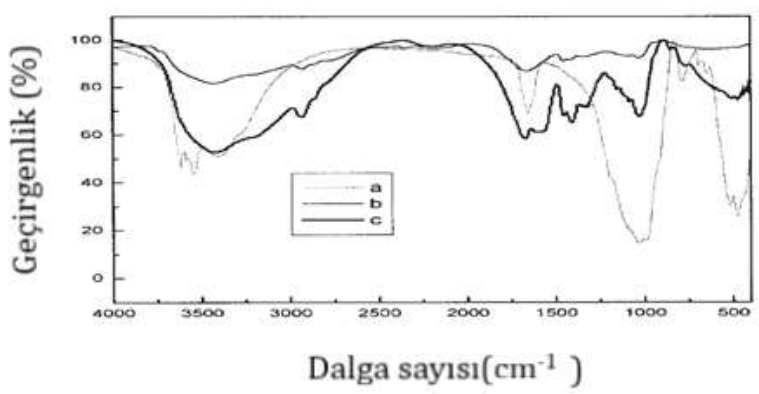

Şekil 3. a) Attapulgit kilinin b) Çapraz bağlı nişastagraft-poli(akrilamit) polimerinin c)nişasta-graftpoli(akrilamit)/attapulgit kompozitinin FTIR spektrumları

Bao vd. (2011) çalışmalarında, Akrilik asit (AA), Akrilamit (Am), 2-Akrilamido-2-metil-1 propansülfonik asit monomerlerini karboksimetilselüloz (CMC) monomerleri üzerine aşılama yaptıktan sonra montmorillonit(MMT) kili ile 
birleștirerek süperadsorban kompozit hidrojelini sentezlemişler, kompozitin fonksiyonel gruplarını tespit edebilmek için FTIR spektrumlarını almışlardır. Şekil 4a'da MMT kiline ait FTIR spektrumunda 3440 cm-1 de görülen pik tabakalar arası sudan kaynaklanan -OH pikine, $1115 \mathrm{~cm}-1$ 'deki pik MMT kilindeki Si-0-Si gruplarına, $796 \mathrm{~cm}-1$ 'deki pik ise Si0-Al grubuna ait olduğu tespit edilmiștir. Şekil 4b' de ise CMC' ye ait FTIR spektrumu verilmiştir. $3443 \mathrm{~cm}-1$ de CMC'ye ait -OH pikine, $1635 \mathrm{~cm}-1$ deki pik karboksilat grubuna $2926 \mathrm{~cm}-1$ pik metilen grubuna aittir. Şekil 4c'deki kompozitin FTIR spektrumu incelendiğinde CMC'de görülen $3443 \mathrm{~cm}-1$ görülen OH pikinin, 3455 ile 3437 cm-1 arasına kaydığı tespit edilmiștir. MMT kiline ait olan $3400 \mathrm{~cm}-1$ civarındaki piklerin kompozitte görülmediği tespit edilmiştir. MMT de bulunan $\mathrm{OH}$ grupları, akrilik monomer grupları ile kimyasal reaksiyona girip, CMC/polimer /MMT kompozit hidrojelini oluşturduğu FTIR spetrumundan tespit edilmiştir [17].

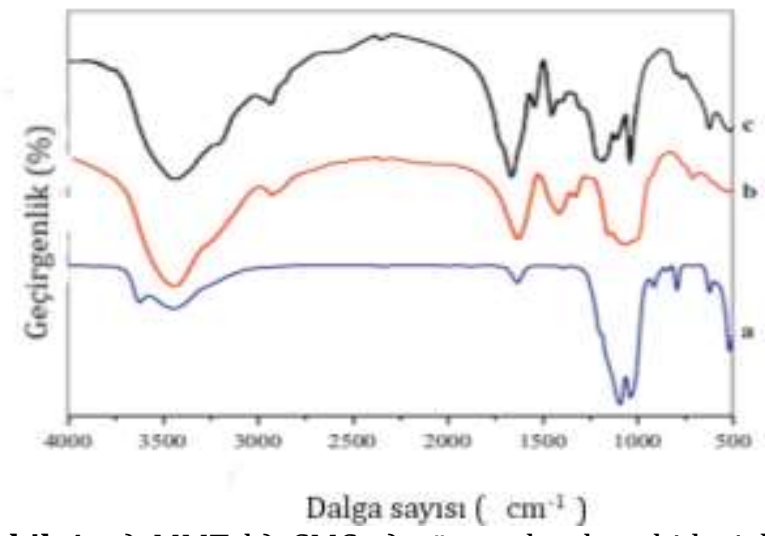

Şekil 4. a) MMT b) CMC c) süperadsorban hidrojel kompozitin FTIR spektrumları

\section{X-Işınları Kırınım Spektroskopisi (XRD)}

X-Işını Kırınım spektroskopisi, ultraviyole ışından daha kuvvetli, gama ışınından daha zayıf enerjili, Xışını kullanılarak yapılan bir analiz yöntemidir. Malzeme üzerine gönderilen X-ışınları örneğin kristal yapısına göre farklı açılarda ve şiddette kırılır. Kırılma ve dağılma verileri toplanarak hassas bir şekilde analiz yapılır [18]. X-ışını kırınımı; polikristallerin yapısının aydınlatılmasında, kristal bozuklukların ve kristal yapıların belirlenmesinde, bilinmeyen malzemelerin tanımlanmasında (örgü sabitigeometrileri) kullanılır [5]. Bir kristale gönderilen Xışınları kristalin düzenli yapısı tarafından saçılır; saçılan ışınlar birbirinin şiddetini artırıcı veya azaltıcı etkiler yaparlar. Bunun nedeni saçıcı merkezler arasındaki mesafenin ışının dalga boyu ile aynı büyüklükte olmasıdır; bu durum ışının kırılmasıyla sonuçlanır [19]. Şekil 5'te X-ışınlarının bir kristal tarafından kırılması verilmiştir [20].

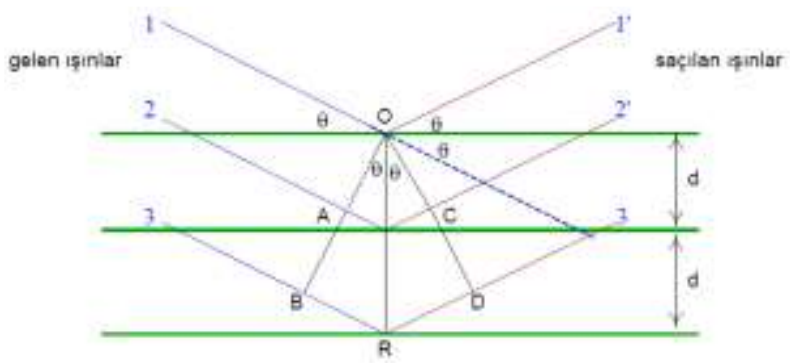

Şekil 5. X-ıșınlarının bir kristal tarafından kırılması

Tabakalı nanokompozitlerde, polimerin tabakalar arasına girmesi nedeni ile tabakalar arası açılmadaki değişim nanometre düzeyindedir ve bu açlmanın büyüklügü XRD analizleri ile saptanır. Tabakaları dağılmış nanokompozitlerde ise yine tabakalar arasına giren polimer nedeni ile tabakalar tümüyle açllarak dağılır, bu değişim de XRD spektrumlarında görülen tabaka ile ilgili kristal örgü piklerinin yok olması ile tespit edilir [21, 22]. Polimer zincirleri sıralı dağıldığında genellikle tabakalar arası uzaklık arttığından kırılan ışınların değerleri azalır. Belirli bir düzen göstermeyen kil tabakalarının rastgele dağıldığı nanokompozit yapılarda, tabakalar arasında çok büyük boşluklar olduğundan XRD diyagramlarında hiçbir kırınım piki gözlenmez. XRD analizinde tabakalar arasındaki uzaklık Bragg denklemi ile hesaplanır ve bu denklem ile sıralı dağılmış yapıları tanımlamak için kullanılır [23].

\section{Bragg denklemi:}

$\mathrm{n} \lambda=2 \mathrm{~d} \operatorname{Sin} \theta$

d : : Düzlemler arası mesafe

$\Theta \quad$ : Gelen X-ıșını ile kristal düzlemi arasındaki açı n : Dalga boyu sayısı

\section{$\lambda$ : Dalga boyu}

XRD uygulamadaki kolaylığı ve yaygınlığı nedeniyle, kil içeren nanokompozit yapıları karakterize etmekte sıklıkla kullanılır. $\mathrm{Bu}$ analiz tekniğinde kil tabakalarının düzenli bir sıra oluşturması (interkele) veya kil tabakalarının düzensiz bir yapı(eksfoliye) oluşturmasına bağlı olarak karakterize edilir. Kil mineral tane büyüklüğüne bağlı olarak daha küçük tabakalar dağılma eğilimi gösterirken daha iri tabakalar aralanmaktadır [24, 25]. Nanokompozit oluşumunu ve kil tabakalarının birbirinden tamamen ayrılıp ayrılmadığını anlamak için belirli teknikler mevcuttur. $\mathrm{Bu}$ tekniklerden, Geniş Açllı X-Işını Kırınımı (WAXD) en çok kullanılanıdır. WAXD'de silikat tabakalarının dağılımından gelen yansımaların yoğunluklarına göre tabakaların aralandığı ya da birbirinden tamamen ayrıldığı kompozitler belirlenebilir. Ancak bazı tabakalı silikatların yansımaları iyi ayırt edilemeyebilir. Bunun sebebi ise bant genişlemesi ve yansıma şiddetidir, bu da WAXD' 
nin dezavantajıdır [26]. SAXS (Dar Açılı X-ışınları saçılması) da silikat tabakalarının nanokompozit içerisinde oluşturduğu nano yapıları yorumlamak için kullanılan bir yöntemdir. Bu teknikte, kil tabakaları arasındaki ortalama uzaklık, kil tabakalarının ortalama kalınlığı ve matriste meydana gelen tabaka yığılmaları belirlenebilir [23]. Numune hazırlanışının kolay olması, homojen ve homojen olmayan yapıların karakterizasyonunda keskin pik vermesi XRD’nin en büyük avantajlarındandır. XRD analizi, nanokompozit yapıların morfolojilerini açıklamada yetersizdir. Bunun nedeni karışık kil yapısı, numune hazırlama ve kil tabakalarının yönlenme durumlarına bağlı olarak (interkele veya eksfoliye) verilerin yorumlamasinda yetersiz olmasıdır $[5,10]$.

Liu vd. (2013) çalışmalarında kitosan/montmorillonit (MMT)/Gümüş (Ag) ve

Kitosan/organomontmorillonit

(OMMT)/Ag nanokompozitlerini sentezlemişlerdir. MMT kil tabakaları arası uzaklık $1.51 \mathrm{~nm}$ olarak belirlenirken, kil organokil haline getirildikten sonra kil tabakaları arasındaki uzaklık $2.20 \mathrm{~nm}$ olarak tespit edilmiștir.

Kitosan/MMT/Ag ve Kitosan/OMMT/Ag nanokompozitlerinin XRD spektrumu incelendiğinde Ag+ iyonunun miktarı arttıkça kompozitin yapısında iyileşmeler olduğu tespit edilmiştir. Kitosan/MMT ve Kitosan/OMMT nanokompozitlerinin XRD spektrumu incelendiğinde interkele yapıda (kil tabakalarının sıralı olması) olduğu gözlemlenirken; Kitosan/MMTAg ve Kitosan/OMMT-Ag nanokompozitlerinin XRD spektrumunun eksfoliye yapıda (kil tabakalarının düzgün yapıda olmaması) oldukları tespit edilmiștir. Şekil 6'da nanokompozitlern XRD spektrumu verilmiştir [27].

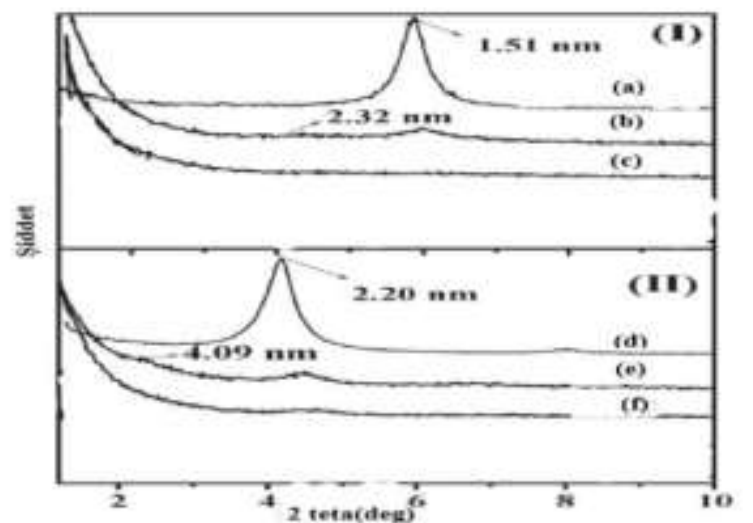

Şekil 6. a) MMT, b) Kitosan/MMT, c)Kitosan/MMT/Ag,d)OMMT,e)Kitosan/OMMT,f)Kito san/O MMT/Ag kil ve nanokompozitlerinin XRD spektrumu

Xu vd. (2019) çalışmalarında, Ca-Rektorit kili ile, polipirol polimerini kullanarak Ca-rektorit/polipirol kompozitini ve bu kompozitin $\mathrm{Cr}$ adsorpsiyonundan sonraki XRD spektrumu Şekil 7'de verilmiştir. Carektorit/polipirol kompozitinin XRD spektrumunda pikte bir azalma görüldüğü tespit edilmiş ve bu sonuç kil yüzeyinin polipirol polimeri ile kaplandığını göstermiștir. Kompozitin eksfoliye yapıda olduğu ve kompozitin $\mathrm{Cr}$ adsorpsiyonunda sonra XRD spektrumu incelendiğinde polipirol homopolimerinin kil üzerindeki pozisyonunda bir değișiklik olmadığı gözlemlenmiştir. Bu durum adsorpsiyondan sonrada kompozitin yapısında bir değişiklik olmadığını göstermiştir [28].

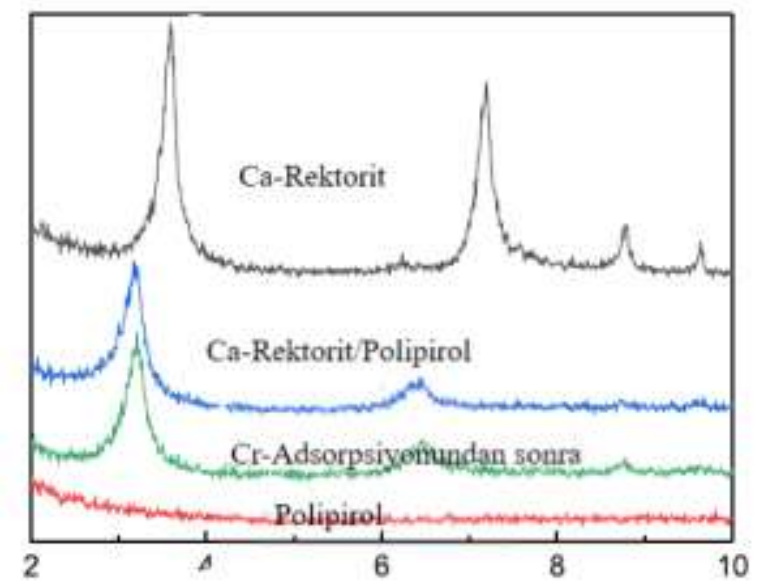

Şekil 7. Ca-Rektorit/polipirol kompozitinin XRD spektrumu

Kumar vd. (2012) çalışmalarında selüloz/kil kompozitini sentezlemişler ve bu kompozitin $\mathrm{Cr}$ (VI) adsorpsiyonunu incelemişlerdir. Kompozitlerin XRD spektrumları incelendiğinde (Şekil 8a) keskin ve kıvrımlı pikler sentezlenen kompozitin eksfoliye yapıda olduğunu göstermiştir. Ayrıca biyopolimerin kil tabakaları arasında düzenli olarak dağıldığı XRD spektrumundan anlaşılmaktadır. Kil yüzeyinin modifiye olması, kilin yüzeyinin organofilik olmasını ve selüloz biyopolimeri ile kil tabakalarının uyumlu bir kompozit olușturduğunu göstermiștir. Șekil 8'de selüloz/kil kompozitinin XRD spektrumu verilmiştir [29].

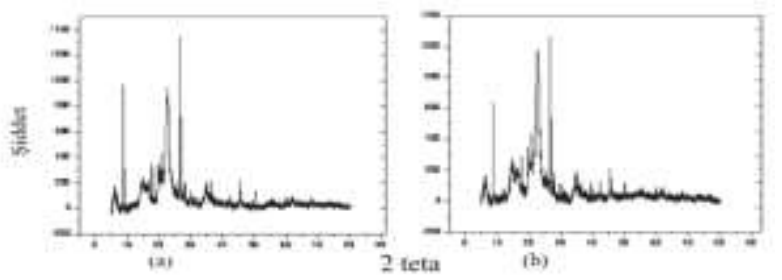

Şekil 8. a) Selüloz/kil kompozitinin XRD spektrumu b)Selüloz/kil kompozitinin $\mathrm{Cr}(\mathrm{VI})$ adsorpsiyonundan sonraki XRD spektrumu

Hu vd. (2016) çalışmalarında, montmorillonit kilinin tabakalar arası uzaklığı $1.26 \mathrm{~nm}$ bulunurken, kitosan/montmorillonit kompozitinin tabakalar arası uzaklığı $1.52 \mathrm{~nm}$ bulunmuştur. Kitosan biyopolimeri kil tabakaları arasına girerek kompozitte kil tabakalarının arasının açılmasını sağlamıştır. Bu bilgi kullanılarak kompozitin istenilen şekilde sentezlendiği ve bu kompoziti farklı koşullar altında $\mathrm{Cu}+2$ adsorpsiyon özellikleri araștırılmıştır. Şekil 9'da 
montmorillonit kili ve kitosan/montmorillonit kompozitinin XRD spektrumu verilmiștir [30].

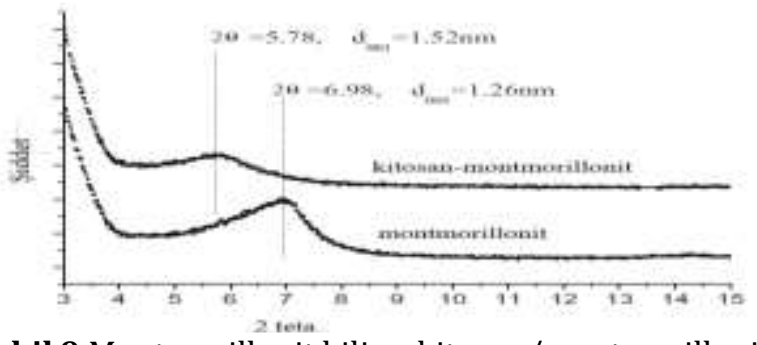

Şekil 9.Montmorillonit kili ve kitosan/montmorillonit kompozitinin XRD spektrumu

\section{Taramalı Elektron Mikroskopisi (SEM)}

SEM bir yüzey görüntüleme tekniği olup, malzeme üzerine yüksek enerjili elektron ışınları gönderilir. Elektron demetinin çarptığı noktada düşük enerjili ikincil elektronlar yüzeyden koparılır ve bu elektronların emisyonu ölçülür. Görüntüler çok yüksek çözünürlüğe sahiptir ve 3 boyutludur. İnterkele yapıya sahip bir polimer/kil nanokompozitinin SEM görüntüsünde birbirine paralel siyah şeritler görülürken, eksfoliye yapıya sahip polimer/kil nanokompozitlerin SEM görüntüsü ise birbirinden bağımsız çizgiler halinde dağılmış şekilde görülür [31,32].

SEM de büyütme oranı 10-50000 arasında olup, istenilen boyuttaki görüntüler dönüștürülerek bir bilgisayar sisteminde toplanır. Taramalı elektron mikroskobu özellikle kompozit malzemelerde kırılma yüzeylerinin incelenmesinde kullanılarak; takviye sistemi ile matris sistemi aralarındaki etkileşim ile matris içindeki tanecik dağılımı hakkında bilgi edinilir [33]. SEM'de, elektron kaynağı $\sim 5$ nm'lik küçük bir noktaya sahip, 200-300 eV ile $100 \mathrm{keV}$ enerji aralığına sahip bir ışın içinde numunenin bütün yüzeyi taranır. Numuneden geri yansıyan elektronlar detektörler tarafından toplanır ve sinyal güçlendiricilerden geçtikten sonra katot ışınları tüpü üzerinde görüntü oluștururlar [5]. SEM'de elde edilen görüntüler; ikincil elektron görüntüleri, geri saçılmış elektron görüntüleri ve elementel X-ışını haritaları olmak üzere 3 tiptedir. Yüksek enerjili birincil elektron bir atom ile etkileștiğinde, atomik elektronlar ile elastik olmayan saçılmaya veya atomik çekirdekler ile elastik saçılmaya maruz kalır. Bir elektron ile elastik olmayan çarpışmada, birincil elektron enerjisinin bir kısmını diğer elektrona transfer eder. Yeterince büyük enerji transferi olduğunda, numuneden diğer elektron yayılır. Yayılan elektronun enerjisi $50 \mathrm{eV}$ 'dan daha düşük olursa, bu elektrona ikincil elektron denir. Geri saçılmış elektronlar, elastik olarak saçılmış yüksek enerjili elektronlardır ve birincil elektronlar ile aynı enerjiye sahiptirler. Numunenin atom numarasının artmasıyla geri saçılma ihtimali de artar. Geri saçılma görüntüleri elementel tanımlama için kullanılmasa da numunenin farklı atom numaralı bölgeleri arasındaki zitlıklar görülebilir [5]. Șekil 10'da TEM'in yapısı verilmiştir [34].

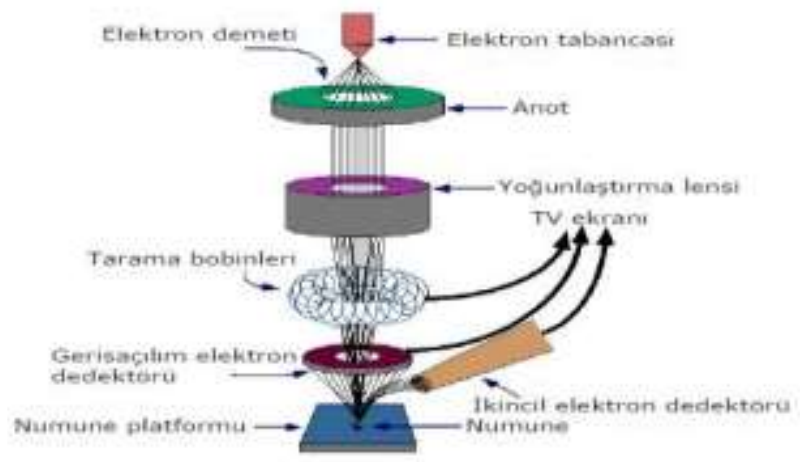

Şekil 10. Taramalı Elektron Mikroskobunun yapısı

SEM için numune hazırlarken numunenin elektriksel olarak yüklenmesini önlenmek amacı ile numune yüzeyi ince bir tabaka ile kaplanır. Bunun için karbon veya altın gibi elementler vakum altında buharlaştırılarak numune üzerine püskürtülür, böylece yüzeyde iletkenlik sağlanmış olur [35]. Sem daha net, üç boyutlu görüntü kalitesi sağlaması, incelenen parçanın şekil ve yapısı hakkında ayrıntılı bilgi vermesi, numunenin spektrum alma öncesi daha az hazırlık çalışmalarına ihtiyacın olmasından dolayı yüzey analizinde kullanılmaktadır [5]. Özellikle polimer kil nanokompozitlerinde kil tabakalarının dağılımı, morfolojisi, kristal yapısı, kil ile polimerin uyum bileşimi ve yönelimi hakkında yüksek enerjili elektron demeti kullanılarak elde edilen görüntülerden bilgi edinilir [10].

Karadağ vd. (2016) çalışmalarında, Akrilamit(AAm) ve Karboksimetilselüloz(CMC), 2-Akrilamido-2metil1-propansülfonikasit(AMPS) ve montmorillonit kilini kullanarak hidrojel yapıda kompozit sentezlemişlerdir. Şekil 11'de hidrojel kompozitlerin SEM görüntüleri incelenerek kompozitlerin boyut ve gözenekli yapısı hakkında detaylı bilgi edinilmiştir. [36]. 


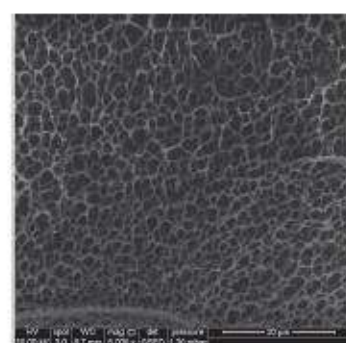

AAm/MMT

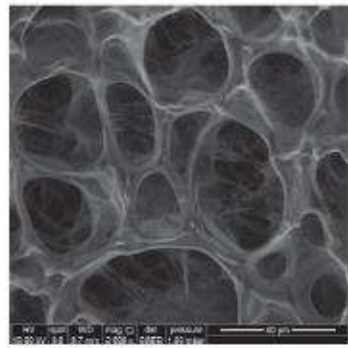

AAm/AMPS/CMC

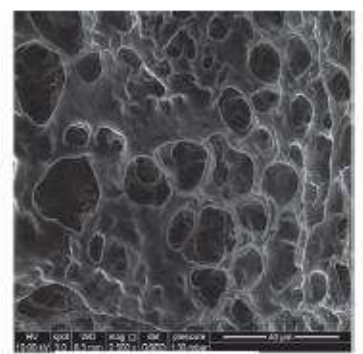

AAm/AMPS

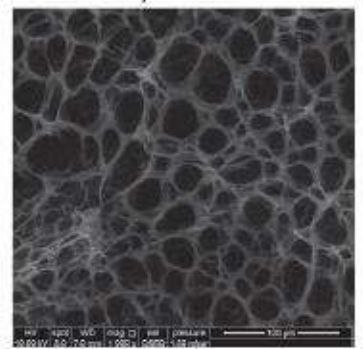

AAm/AMPS/CMC/MMT
Şekil 11. 240 mg AMPS içeren hidrojel kompozitlerin SEM görüntüsü

Sermsantiwanit vd. (2012) çalışmalarında, polilaktikasit (PLA)polimeri ile $\mathrm{Na}+$ Cloisite ve Cloiste30B killerini kullanarak nanokompozit sentezlemişler ve bu nanokompozitlerin SEM görüntülerini incelemişlerdir (Şekil 12). SEM görüntüleri incelendiğinde, kompozitlerin kürelerden oluştuğunu bu kürelerin boyutlarının farklı olduğu Şekil 12'de görülmüștür. PLA örneğindeki SEM görüntülerinde küreler diğer kompozitlerin SEM görüntülerine göre daha büyüktür. Kompozit oluştuktan sonra PLA kürelerin küçüldüğü gözlemlenmiştir. Na+ Cloisite ve Cloiste30B kili ile hazırlanan örneklerde gözlemlenen küçük boyutlardaki partiküllerin bazı alanlarda düz film oluşturmak için birleștikleri tespit edilmiștir [37].

Lei vd. (2006) çalışmalarında polipropilen/Cloisite $\mathrm{Na}+$ ve polipropilen /Cloisite 15A kompozitlerini sentezlemişler ve SEM görüntülerini incelemişlerdir. Buna göre polipropilen matrisi içinde kil tabakalarının büyüklü küçüklü topaklandığı fakat bu topaklanmalar simetrik olmadığı ve matris içerisine rastgele dağildı $\breve{~}$ için topaklanmaların boyutu hakkında bilgi edinilememiştir. Farklı boyutlarda gözlemlenen topaklanmalar parçacıkların yönelimine bağlıdır. Kil konsantrasyonu ve kilin türü topaklanmada büyük rol oynar. Şekil 1 4'te Cloisite $\mathrm{Na}+$ /polipropilen kompozitinin SEM görüntüleri incelendiğinde büyük topaklanmaların olduğu ve kil ile polimer matrisi arasında zayıf etkileşim olduğunu tespit etmişlerdir. Şekil 14'te verilen Cloisite 15A/polipropilen kompozitinin SEM görüntüleri incelendiğinde kil topaklanmasının boyutunun, Şekil 15a'da Na-Cloisite ile yapılan kompozite göre küçüldüğünü gözlemlemişlerdir. Bu durum Cloisite $15 \mathrm{~A}$ kili ile polimerin birbiriıyle uyumlu olduğunu göstermiştir. [39].
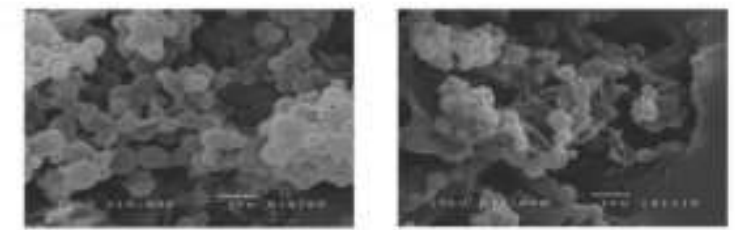

a)

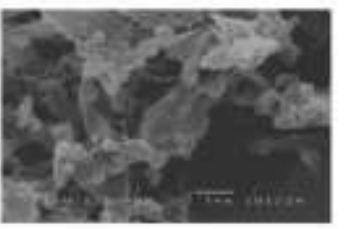

Şekil 12. a) Polilaktikasitin (PLA) SEM görüntüsü b) PLA/Cloisite 30B kompozitinin SEM görüntüsü $\quad$ c) PLA/Cloisite Na+kompozitinin SEM görüntüsü

Burgaz vd. (2014) çalışmalarında, farklı yüzdelerde Cloisite $\mathrm{Na}+$ kilini, polietilenoksit polimeri ile etkileştirerek, polietilenoksit(PEO)/Cloisite $\mathrm{Na}+$ nanokompozitlerini sentezlemişlerdir. Şekil 13'te PEO/Cloisite 30B nanokompozitinin SEM görüntüleri verilmiştir. Farklı oranlarda kil içeren nanakompozitlerde, killerin topaklanması SEM görüntülerinde parlak noktalarda görülmektedir. Kil konsantrasyonunun artmasiyla topaklanmanın daha fazla arttığı SEM görüntülerinden anlaşılmıştır. Kil parçacıkları PEO nanokompozitinde ağırlıkça \%10'luk kil içeren örnekte daha iyi bir dağılım gösterdiği tespit edilmiştir. Kil miktarının artması nanokompozitte bölgesel topaklanmalara yol açmıştır [38].
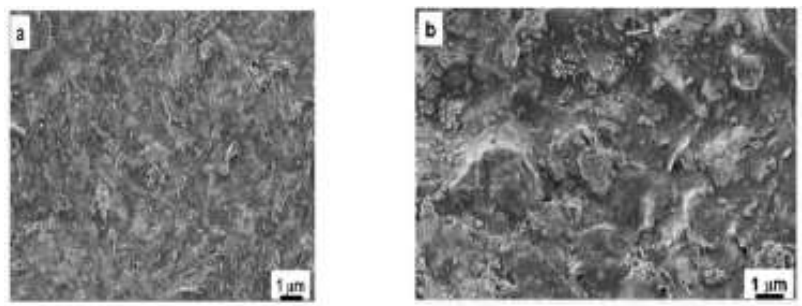

Şekil 13. a) \%10 kil içeren PEO/Cloisite $\mathrm{Na}+$ nanakompozitinin SEM görüntüsü b) \%20 kil içeren $\mathrm{PEO} /$ Cloisite $\mathrm{Na}+$ nanakompozitinin SEM görüntüsü
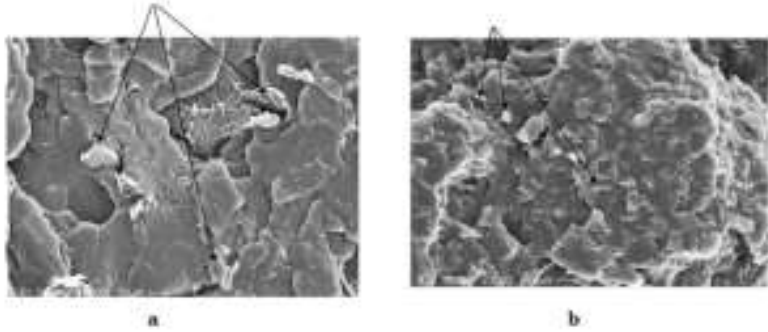

Şekil 14. a) Cloisite Na/Polipropilen kompoziti b) Cloisite 15A/Polipropilen kompozitlerinin SEM görüntüleri

\section{Geçirimli Elektron Mikroskobu (TEM)}

Geçirimli elektron mikroskobu (TEM) nanometre mertebesinde çok küçük ve ince alanlardan, milyon katı büyütmelerle malzemenin kristalografik ve 
morfolojik bilgilerine aynı anda ulașılmasını sağlar [40]. TEM'de, elektronlar $100 \mathrm{KeV}$ veya daha yükseğe (1 MeV) hızlandırılır, yoğunlaștırıcı mercek tarafından ince (200 nm'den daha düşük) bir numune üzerine yansitılır ve numunenin içinden geçirilir [5]. TEM'in en büyük avantajı, yüksek büyütmeli bir görüntü sağlayabilmesi ve tek bir örnekten hem görüntü hem de kırınım bilgisi elde edilmesidir. Bu analiz tekniğinin dezavantajı, numune hazırlama işlemi sırasında tüm numunenin temsili bir görüntüsünü elde etmek için çok sayıda resim çekmeyi gerektirdiğinden oldukça zaman alıcıdır [10]. Şekil 15 'te TEM ve SEM'in çalışma prensibi verilmiştir [41].

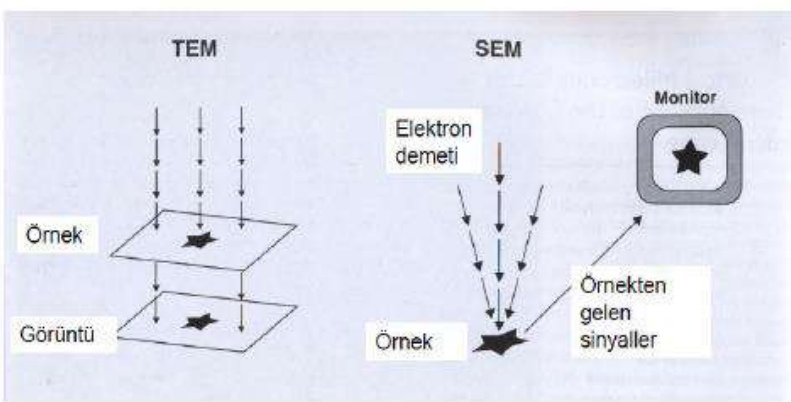

Şekil 15. TEM ve SEM'in çalışma prensibi

TEM, dağılımları ve hataları görüntülemekte ve farklı fazları belirlemekte kullanılabilir. Morgan ve Gilman polimer nanokompozitleri hem XRD hem de TEM ile karakterize etmiş, kompozitin tam olarak çeşidinin belirlenebilmesi için iki yöntemin birlikte kullanılması gerektiğini göstermişlerdir. Kompozitin aralanmış ya da dağılmış olmasının dışında tabakalanma biçimi ya da düzenli veya düzensiz dağılmış olmasının belirlenebilmesinde, XRD'nin tek bașına kompoziti karakterize etmekte yetersiz kaldığı saptanmıştır [42]. Tabakalı polimer kil nanokompozitlerinin TEM görüntülerinden kilin polimer zincirleri arasında dağılıp dağılmadığı tespit edilir ve kalitatif karakterizasyona imkân sağlar [43].

Manies vd. (2001) çalışmalarında, Propilen/Montmorillonit (MMT) nanokompozitini sentezlemişler, nanokompozitin morfolojisinin belirlenmesi için TEM görüntülerini incelemişlerdir. Nanakompozitin TEM görüntüsü A noktası ile belirtilen yerler MMT kilinin taktoit interkele yapıda olduğunu, B noktası ile belirtilen yerler ise MMT kil tabakalarının düzenli olmayan eksfoliye yapıda olduğu Şekil 16'da verilen Propilen/Montmorillonit kil nonokompozitinin TEM görüntüsünden tespit edilmiştir [44].

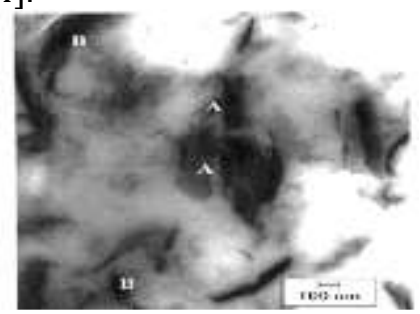

Şekil 16. Propilen/MMT kil nonokompozitinin TEM görüntüsü
Potarniche vd. (2012) çalışmalarında, kitosan/MMT nanokompozitini sentezlemişler ve kompozitin Şekil 17 'de verilen TEM görüntüleri incelenmiştir. NaCloisite-Kitosan kompozitinin TEM görüntüleri incelendiğinde interkele düzensiz yapılar ile kısmen eksfoliye yapılar gözlenmiştir. Kil tabakaları arasına kitosan biyopolimerinin girmesiyle kil tabakaları arasındaki uzaklığın arttığı XRD sonuçlarından anlaşılmıştır. Kompozitin hem XRD hem de TEM sonuçlarının birbirini desteklediği gözlemlenmiştir. Kil içeren kompozit yapılarda kantitatif sonucun net olarak elde edilebilmesi için TEM görüntülerinin yanında XRD sonuçlarının da alınmış olması nanokompozitinin yapısının aydınlatılmasını sağlar [45].

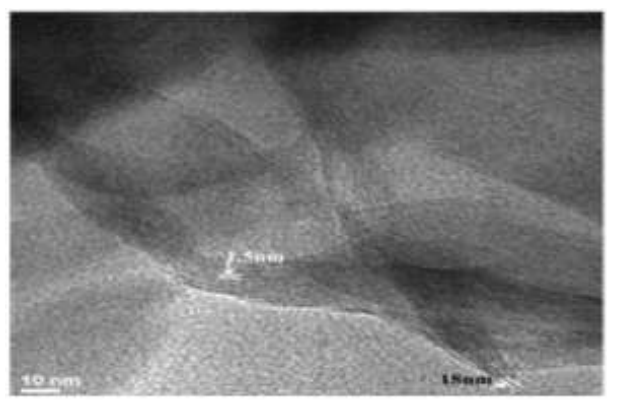

Şekil 17. Kitosan /MMT nanokompozitinin TEM görüntüsü

Gogoi vd. (2016) çalışmalarında, çapraz bağlı kitosan/ MMT nanokompozitini sentezlemişler ve TEM görüntülerini almışlardır. Şekil 18'de verilen TEM görüntüleri incelendiğinde Şekil 18a da kitosan/glutaraldehitin, Şekil 18b'de kitosan/MMT/glutaraldehit kompozitinin 100 nm' de çekilmiş TEM görüntüleri Şekil $18 c^{\prime} d e$ ise $20 \mathrm{~nm}$ 'de kitosan/MMT/glutaraldehit çapraz bağlı kompozitinin TEM görüntüleri verilmiştir. MMT yüklü çapraz bağlı polimerlerin iki farklı TEM görüntüleri incelendiğinde koyu çizgilerin MMT den kaynaklı olduğu görülmüştür. Çapraz bağlı polimer matrisi içerisinde MMT kil tabakalarının iyi dağılım gösterdiği hem TEM hem de XRD sonuçlarından çıkarılmıştır [46]. 

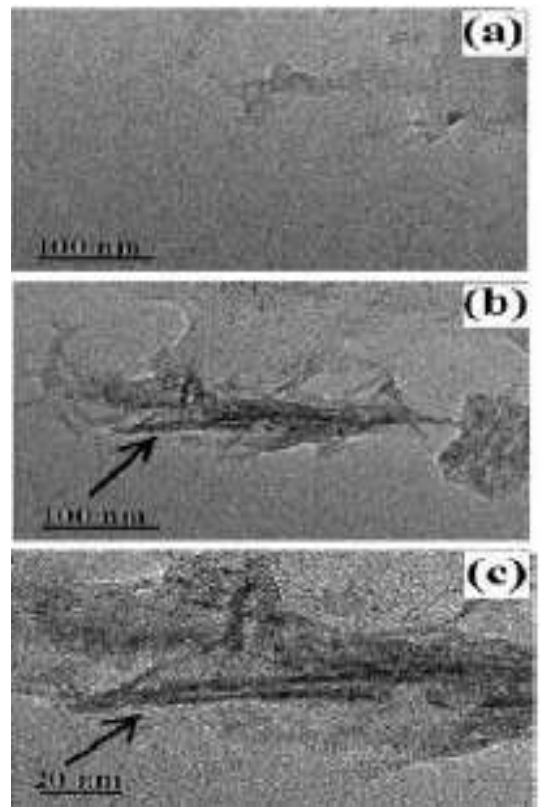

Şekil 18. a) Kitosan/glutaraldehit b)Kitosan/MMT/ glutaraldehit kompozitinin $100 \mathrm{~nm}$ 'deki TEM görüntüsü c) Kitosan/MMT/ glutaraldehit kompozitinin $20 \mathrm{~nm}$ 'deki TEM görüntüsü

Sabaa vd. (2015) çalışmalarında, Karboksimetilkitosan/polivinilalkol/MMT

kompozitini sentezlemişler. Şekil 19a) da MMT kilinin Şekil 19b) de kompozitin TEM görüntülerini incelemişlerdir. MMT'nin TEM görüntüsü yaprak gibi şekil verirken, kompozitin TEM görüntüsünün küçük hidrojel kompozit verdikleri tespit edilmiştir [47].
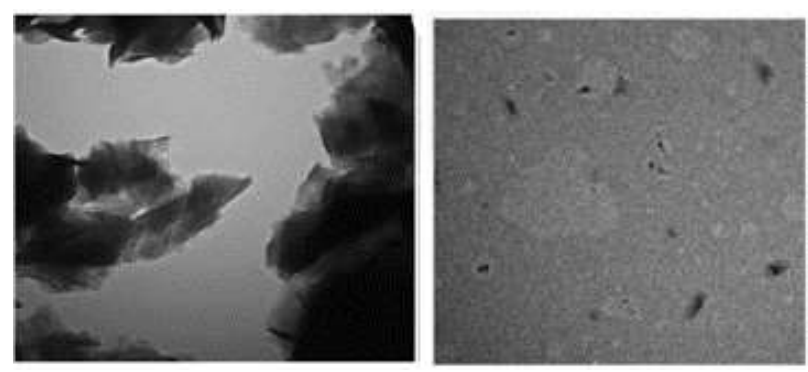

Şekil 19. a) MMT kilinin TEM görüntüsü b)Karboksimetilkitosan/Polivinilalkol/MMT kompozitinin TEM görüntüsü

Yeniova vd. (2010) çalıșmalarında, poli(stiren-b(etilen-ko-bütilen)-b-stiren) kopolimer matrisine MMT kilini ilave ederek kompozit sentezlemişler ve TEM görüntülerini almışlardır (Şekil 20) . XRD sonuçlarında net olmayan bazı sonuçlar TEM görüntülenin alınmasıyla netleşmiştir. Siyah noktalar kil topaklarını göstermektedir. İyi dağılım göstermiş kompozitlerde bu lekeler, dolgunun tabakalara ayrıldığını göstermektedir. TEM görüntülerinde gri alanlar polimer matrisini gösterirken, beyaz alanlar elastomerik fazı gösterir. TEM görüntülerinden kil parçacıklarının hem polistiren hem de elastomer arasında iyi dağılım olduğunu göstermektedir [48].
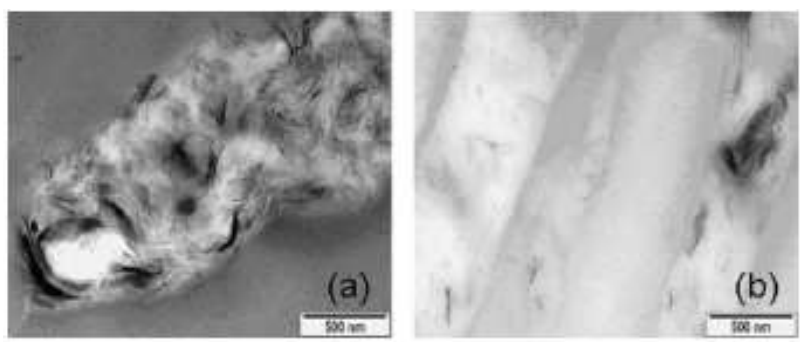

Şekil 20. a) Polistiren/Elastomer/Cloisite 25A Elastomer:\%93, b) Polistiren/Elastomer/Cloisite 25A Elastomer:\%83 kompozitlerinin TEM görüntüsü

\section{Atomik Kuvvet Mikroskopisi (AFM)}

Atomik kuvvet mikroskopisi (AFM), moleküler büyüklüklerin görüntülenmesine olanak tanıyan görüntüleme tekniklerindendir. Katı faz katalizör yüzeyleri gibi yüzeyin morfolojik ve topografik yapısı ve yüzey bileşenlerinin incelenmesi çalışmalarında kullanılmaktadırlar. AFM, nanokompozitin yüzey dokusu, pürüzlülük, morfoloji, boyut bilgisi (yükseklik, genişlik ve uzunluk) ve hacim dağılımları gibi özellikleri karakterize etmek için de kullanılır. AFM, nanometre ölçeği çözünürlüğünde üç boyutlu bir görüntü sağlayabilme özelliğine ve çeşitli ortamlardaki (ortam havası, kontrollü atmosferler ve sıvı dispersiyonlar) numuneleri karakterize etmekte kullanılır. Temel olarak, bu alet bir keskin uç ile numune yüzeyi arasındaki Van der Waals etkileşimini (temas modunda veya temassiz modda) temel alarak çalışır [10]. Sistem temel olarak, birkaç atomdan oluşan bir iğnenin elektrik kontrol elemanları aracılı̆̆ı ile yüzeye çok yakın olarak, incelenen yüzey üzerinde üç boyutta hareket ettirilmesine dayanmaktadır. İğnenin konumundaki bozulmalar bir lazer işığı tarafından algılanır ve büyütülür. Böylece ince tipin yüzeydeki itme ve çekme kuvvetler ile şeklinin bozulması ile yüzey topografyası çıkarılmış olur. AFM yardımıyla yüzey topografyası nanometre seviyesinde belirlenmiş olur. Şekil 21'de AFM yüzey analizinin şematik gösterimi verilmiştir [49].

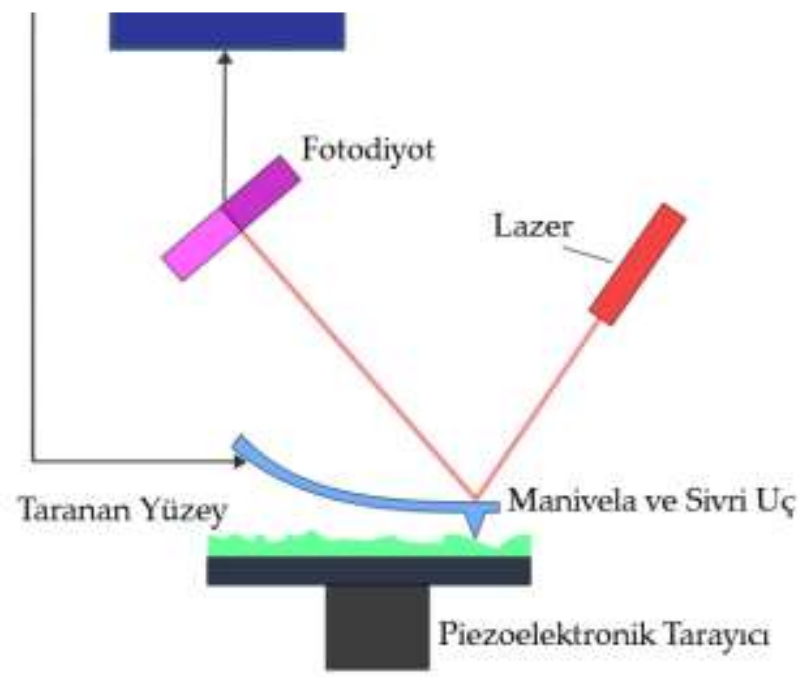

Şekil 21. AFM yüzey analizinin şematik gösterimi 
AFM, iletken olmayan yüzeyler için kullanılabilir. Yöntem ile katı örnek yüzeylerine ilișkin atomik boyutta çözünürlüğe sahip görüntüler elde edilebilir. Kullanım alanları; yarı iletkenlerde silikon yüzeylerin karakterizasyonunda, bunların yüzey hatalarının tespitinde ve manyetik merkezlerin görüntülenmesinde; biyoteknoloji alanında DNA, kromatin, protein /enzim etkileşiminde, mebran virüslerin vb görüntülenmesinde yararlanılır [20].Membran yüzey karakterizasyon tekniklerinden AFM; örnek hazırlamasında kolaylığı hem sıvı ortamda hem de hava ortamında ölçüm sağlaması açısından bilim insanlarınca uzun süredir kullanılmaktadır [50, 51]. AFM ile yüzeylerin pürüzlülüğü, porozitesi, gözenek dağllımı, yapılan kaplamanın kalınlığı hakkında bilgi alınabilir [52-54].

Lee vd. (2006) çalışmalarında, farklı oranda kil içeren poliüretan/kil nanokompozitlerini sentezlemişler, yüzey tapografyasını incelemek için nanokompozitlerin AFM görüntüsü alınmıştır. Şekil 22'de nanokompozitlerin AFM görüntüsü verilmiștir. Poliüretan yönünden zengin olan nanokompozitlerde (A) faz görüntüsü parlaktır. $\% 5$ kil içeren nanokompozitlerin yüzeyinde koyu bölgelerde kil topaklanması gözlemlenmiştir. (B)nanokompozitinin AFM görüntüsü (C) nanokompoziti ile karşılaştırıldığında (C) nanokompozitinde kiltopaklanmasının daha çok olduğu Şekil 22'deki AFM görüntülerinden anlaşılmıştır [55].

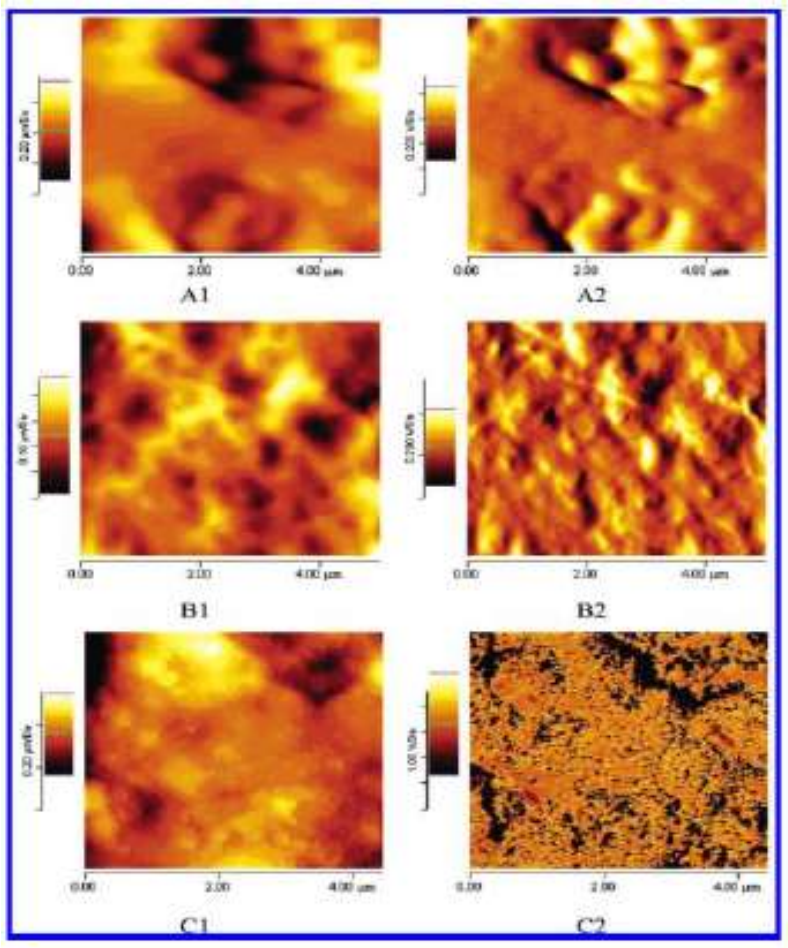

Şekil 22. $\% 0, \% 1, \quad \% 5$ oranında kil içeren Poliüretan/kil nanokompozitlerinin AFM görüntüsü

Das vd. (2013) çalışmalarında, (60/40) Karboksimetilselüloz (CMC)/Montmorillonit (MMT) nanokompozitini sentezlemişler ve yüzey özelliklerini belirlemek için AFM görüntüsü alınmıștır Șekil 23 a'da kısmen kaplanmış ince tabaka CMC'yi gösterirken, pürüzlü yüzey nanokil üst yüzeyini göstermektedir. AFM görüntüsünde bozulmamış nanokil yüzeyini düz olarak görülmektedir ve bu yüzeyin yüksekliği Şekil 23 b'de görülmektedir ve ortalama yüksekliği 1 nanometredir [56].
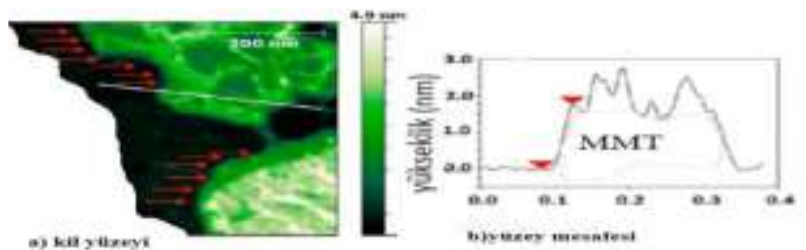

Şekil 23. CMC/MMT nanokompozitinin AFM görüntüsü

Matusik vd. (2011) çalışmalarında, polilaktikasit (PLA) /kaolinit kompozitini sentezlemişler yüzey analiz ölçümünde AFM'den yararlanmışlardır. AFM ölçümü kompozitin homojenliğinin tespit edilmesi için TEM görüntülerinden de yararlanmışlardır. PLA ile PLA /kaolinit kompozitinin AFM görüntüleri Şekil 24 'te verilmiştir. Hem AFM hem de TEM görüntüleri incelendiğinde PLA'ya kaolinit kilinin katılması kompozitin homojen olarak bir görüntü elde edildiğini göstermiş ve kompozitin mekanik özelliklerinin de arttığını öngörmüşlerdir [57].
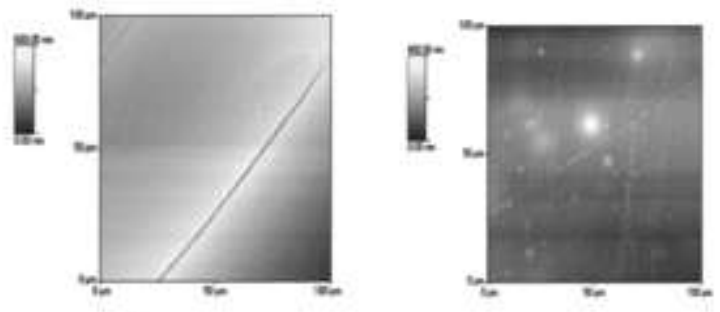

b

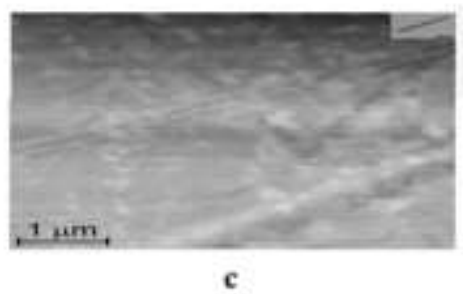

Şekil 24. a)PLA'nın AFM görüntüsü b) PLA/Kaolinit kompozitinin AFM görüntüsü c) PLA/Kaolinit kompozitinin TEM görüntüsü

Darie vd. (2014) çalışmalarında, PLA polimeri ile PLA/Cloisite 30B kompozitini sentezlemişler ve hem 2 boyutlu hem de 3 boyutlu AFM görüntülerini çekmişlerdir (Şekil 25). PLA bir organokil olan Cloisite 30B ilave edilmesi kompozitte homojen bir görüntü sağladığı AFM görüntüsünden anlaşılmaktadır. Polimerik substrat yüzeyi ve hidrofik yapısı kil ilavesi ile artmıştır [58]. 

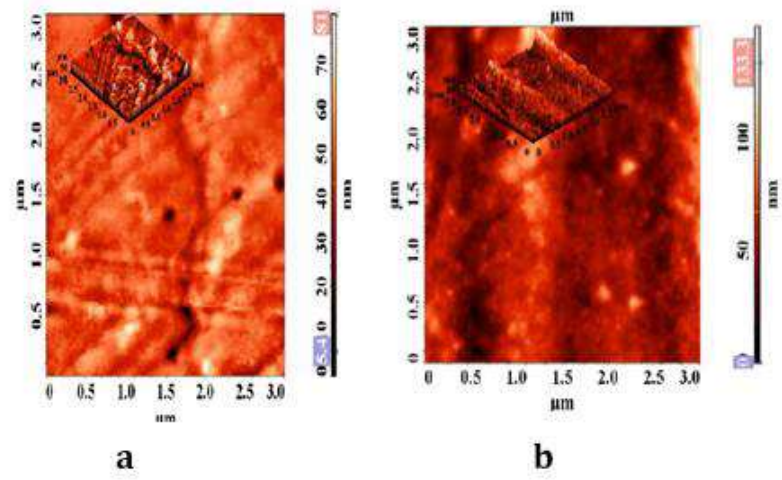

Şekil 25. a) PLA'nın AFM görüntüsü b) PLA/Cloisite 30B kompozitinin AFM görüntüsü

\section{Tartışma ve Sonuç}

Polimerler; işleme kolaylıkları, uygun fiyatları ve modifiye edilebilmeleri nedeniyle, endüstride geniş bir kullanım alanına sahiptirler. Polimerlere kil takviyesi, son zamanlarda revaçta olan konulardandır. Farklı polimerlere belli oranlarda farklı kil türlerinin ilavesiyle, sentezlenen kompozitte termal ve mekanik özelliklerinde iyileșmeler olduğu, son yapılan çalışmalarda görülmektedir. Kompozitteki iyileşmelerin gözlemlenebilmesi için, bazı yüzey analiz tekniklerinin kullanılması gerekmektedir. Bu çalışmada, sentezlenen polimer/kil kompozitin karakterizasyonunda kullanılan FTIR, SEM, TEM, XRD, AFM, gibi bazı analiz metotları irdelenmiştir. Kompozitlerin yüzey analizinde kullanılan bu teknikler; malzemenin yüzey özelliklerinin incelenmesinde, kimyasal yapılarının aydınlatılmasında, hidrofobik-hidrofilik özelliklerin tespitinde, malzeme performansı, morfolojisi ve topoğrafyası gibi özelliklerin tespitinde kullanılmaktadır. $\quad \mathrm{Bu}$ teknikler, sadece nanokompozitler için değil; tıp, medikal ve sağlık gibi alanlarda kullanılan biyomalzemelerin yüzey morfolojisinin belirlenmesinde de kullanılmaktadır. (Biyo)polimer/kil kompozitlerin gelecek yıllarda birçok endüstriyel sektörde önemli kullanım alanlarına sahip olacağı düşünülmektedir ve bahsi geçen tekniklerle sentezlenen kompozitlerin karakterizasyonunun yapılması öngörülmektedir.

\section{Kaynakça}

[1] Yoruç, A.B.H., ve Uğraşkan, V., 2017. Yeşil Polimerler ve Uygulamaları. Afyon Kocatepe Üniversitesi Fen ve Mühendislik Dergisi, 17, 318337.

[2] Ke, Y.C., ve Stroeve P., 2005. Polymer-Layered Silicate and Silica Nanocomposites. 1st ed., Elsevier Science, 398.

[3] Gülcan, M. 2012. Anorganik Kimyada Spektroskopik Yöntemler

https://docplayer.biz.tr./1287011.

(Erişim Tarihi:30.10.2020)

[4] Merrett, K., Cornelius, R.M., Mcclung, W.G., Unsworth, L.D., Sheardown, H., 2002. Surface Analysis Methods for Characterizing Polymeric
Biomaterials. Journal of Biomaterials Science Polymer Edition, 13, 593-621.

[5] Şentürk, E., Okur, İ., Duman S., ve Akbulut, S., 2012. Nanoteknolojiye Giriş Kitabı. Değişim Yayıncılık, 291.

[6] Şengel, C.T. ve Hasçiçek, T.C., 2009. Polimerik Nanopartiküler İlaç Taşıyıcı Sistemlerde Yüzey Modifikasyonu. Ankara Eczacılık Fakültesi Dergisi, 38, 137-154.

[7] Kalyoncuoglu, U.T., Yilmaz, B., Koc, S.G., Evis, Z., Arpaci, P.U., Kansu, G., 2018. Investigation of Surface Structure and Biocompatibility of Chitosan-Coated Zirconia and Alumina Dental Abutments. Clinical Implant Dentistry and Related Research, 20, 1022-1029.

[8] Solomons, G., ve Fryhle, C., 2002. Organik Kimya. 7. baskı, Literatür Yayıncılık, İstanbul, 76-78.

[9] Snoussi, Y., Khalil, A.M., Strzemiecka, B., Voelkel, A., Chehimi, M.M., 2017. Surface Analysis of ClayPolymer Nanocomposites. Clay Polymer Nanocomposite, 11, 363-411.

[10] Bee, S.L., Abdullah, M.A.A., Bee, S.T., Sin, L.T., Rahmat, A.R. 2018. Polymer Nanocomposites Based on Silylated-Montmorillonite: A Review. Progress in Polymer Science, 85, 3-37.

[11] Bao, Y., Maa, J., Li, N., 2011. Synthesis and Swelling Behaviors of Sodium Carboxymethyl Cellulose-g-Poly(AA-co-AM-co-AMPS)/MMT

Superabsorbent Hydrogel. Carbohydrate Polymers, 84, 76-82.

[12] Karadağ, E., Kasim, Z.D., Kundakcı, S., Üzüm Ö.B., 2017. Acrylamide/Potassium 3-Sulfopropyl Methacrylate/Sodium Alginate/Bentonite Hybrid Hydrogels: Synthesis, Characterization and İts Application in Lauths Violet Removal from Aqueous Solutions. Fibers and Polymers, 18, 921.

[13] Aranda, P., Hitzky, E.R., 1999. Poly(etylene oxide)/NH4+-Smectite Nanocomposites. Applied Clay Science, 15, 119-135.

[14] Ekici, S., Işıkver, Y., Saraydın, D., 2005. Poly(Acrylamide-Sepiolite) Composite Hydrogels: Preparation, Swelling and Dye Adsorption Properties. Polymer Bulletin, 57, 231-241.

[15] Wang, Y., Zhang, X., Wei, H., Zhang, B., Xiang, X., Chen, R., 2015. Synthesis of Poly(AA-co-AM) Superabsorbent Composites by Reinforcement of Halloysite Nanotubes. Polmer Composites, 36, 229-235.

[16] Li, A., Liu, R., Wang, A., 2005. Preparation of Starch-Graft-Poly(Acrylamide)/Attapulgite Superabsorbent Composite, Journal of Applied of Polymer Science , 98, 1351-1357.

[17] Bao,Y., Ma, J., Li, N., 2011. Synthesis and Swelling behaviors of sodium carboxymethyl cellulose-gpoly(AA-co-AM-co-AMPS)/MMT superabsorbent hydrogel, Carbohydrate Polymers, 84, 76-82.

[18] Guozhong, C., 2004. Nanostructures and Nanomaterials: Synthesis, Properties and 
Applications. Imperial College Press, 2nd ed., London, 329-412.

[19] Beșergil, B., 2015. Enstrumental Analiz Temel İlkeler, 1. Baskı, Gazi Kitabevi, 833.

[20] Skoog, D.A., Timot, F.J.H., 2008. Enstrumental Analiz İlkeleri. 6. Baskı, Ankara, Bilim yayıncılık, 1038.

[21] Alexandre, M., Dubois, P., 2000. Polymer-Layered Silicate Nanocomposites: Preparation, Properties and Uses of New Class Materials. Materials Science and Engineering R: Reports, 28, 1-63.

[22] Ray, S.S., Okamoto, M., 2003. Polymer/Layered Silicate Nanocomposites: A Review from Preparation to Processing. Progress in Polymer Science, 28, 1539-1641.

[23] Jokela, K., Vaananen, A., Torkkeli M., Starck, P., Serimaa, R., Lofgren, B., Seppala, J., 2001. Differential Scanning Calorimetry, Small-Angle XRay Scattering, and Wide-Angle X-Ray Scattering on Homogeneous and Heterogeneous Ethylene$\alpha$-Copolymers. Journal Polymer Science B Polymer Physic, 39, 16, 1860-1875.

[24] Çankaya, N., Sökmen, Ö., 2016. Kitosan Kil Nanokompozitleri. Politeknik Dergisi, 19, 283295.

[25] Okada, A., Usuki, A., 1995. The Chemistry of Polymer-Clay Hybrids, Materials Science and Engineering, 3, 109-115.

[26] Nguyen, Q.T., Baird, D.G., 2006. Preparation of Polymer-Clay Nanocomposites and Their Properties. Advances in Polymer Technology, 25, 270-285.

[27] Liu, B., Shen, S., Luo, J., Wang, X., Sun, R., 2013. One-Pot Green Synthesis and Antimicrobial Activity of Exfoliated Ag NP-Loaded Quaternized Chitosan/Clay Nanocomposites. The Royal Society of Chemistry, 39714-9722.

[34] Atay, A. 2014. Daha Yakın Olmak İçin Elektron Mikroskopları

http://www.acikbilim.com/2014/02/dosyalar/dahayakin-olmak-icin-elektron-mikroskoplari-2.html (Erişim Tarihi:30.10.2020)

[35] Cheremisinoff, N.P., 1996. Polymer Characterization Laboratory Techniques and Analysis, 1st ed., William Andrew, A.B.D., 262.

[36] Karadă̆, E., Nalbantoğlu, A., Kundakçı S., Üzüm, Ö.B., 2016. Uranyl Ion Sorption Characteristics of Novel Polymer/ Montmorillonite/Carboxymethyl CelluloseComposite Biosorbent-Based AAm/AMPS Hydrogels and Semi-IPNs", Advances in Polymer Technology, 37, 1-11.

[37] Sermsantiwanit, K., Phattanarudee, S., 2012. Preparation of bio-based nanocomposite emulsions: Effect of clay type. Progress in Organic Coatings, 74, 660-666.

[38] Burgaz, E., Yazici , M., Kapusuz , M., Alisir, S. H., Ozcan, H., 2014. Prediction of Thermal Stability, Crystallinity and Thermomechanical Properties of Poly(ethylene oxide)/Clay Nanocomposites with Artificialneural Networks. Thermochimica Acta, 575, 159-166.
[28] Xu, Y., Chen, J., Chen R., Yu P., Guo ,S., Wang ,X., 2019. Adsorption and Reduction of Chromium(VI) from Aqueous Solution Using Polypyrrole/Calcium Rectorite Composite Adsorbent. Water Research,160,148-157.

[29] Kumar, A. S. K., Kalidhasan, S., Rajesh,V., Rajesh, N. 2012. Application of Cellulose-Clay Composite Biosorbent toward the Effective Adsorption and Removal of Chromium from Industrial Wastewater. Industrial Engineering Chemistry Research, 51, 58-69.

[30] Hu, C., Hu, H., Zh, J., Deng, Y., Li, C., 2016. Adsorption of $\mathrm{Cu} 2+$ on Montmorillonite and Chitosan-Montmorillonite Composite Toward Acetate Ligand and the $\mathrm{pH}$ Dependence. Water Air Soil Pollut, 227,362.

[31] Krishnamoorti, R., Vaia, A.R., Giannelis, E.P., 1996. Structure and Dynamics of Polymer Layered Silicate Nanocomposites. Chemistry of Materials, 8, 1728-1734.

[32] Wang, K., Chen , C., Wu, K., Toh , M.L., He, C., Yee, A.F., 2005. Epoxy nanocomposites with highly exfoliated clay: mechanical properties and fracture mechanisms. Macromolecules, 38, 788800.

[33] Bower, D.I., 2002. An Introduction to Polymer Physics, Cambridge University Press, 1st ed., New York, A. B. D., 425.

[39] Lei, S.G., Hoa, S.V., That, M.-T. T. 2006. Effect of Clay Types on the Processing and Properties of Polypropylene Nanocomposites. Composites Science and Technology, 66, 1274-1279.

[40] Ersöz, A., 2010. Aletli Analiz Teknikleri. Anadolu Üniversitesi Yayınları, 359.

[41] Akgün, A., Emrem, E., 2015. Elektron Mikroskobu. https://www.slideshare.net/ErayEmrem/elektr on-mikroskobuna-genel-bak.

(Erişim Tarihi:02.11.2020)

[42] Morgan, A.B., Gilman, J.W., 2003. Characterization of Poly-Layered Silicate (clay) Nanocomposites by Transmission Electron Microscopy and X-Ray Diffraction: A Comparative study. Journal of Applied Polymer Science, 87, 1329-133,8.

[43] Nguyen, Q.T., Baird, D.G., 2006. "Preparation of Polymer-Clay Nanocomposites and Their Properties. Advances in Polymer Technology, 25, 270-285.

[44] Manias, E., Touny, A., Wu, L., Strawhecker, K., Lu, B., Chung, $\quad 2001$. Polypropylene/Montmorillonite Nanocomposite Materials. Review of Synthetic Routes and Materials Properties. Chemistry of Materials, 13, 3516-3523.

[45] Potarniche C. G., Vuluga Z., Donescu D., Christiansen J. de C., Eugeniu, V., Radovici C., Serban

S., Ghiurea M., Somoghi R., Beckmann S., 2012. Morphology Study of Layered Silicate/chitosan nanohybrids. Surf. Interface Anal.,44, 200-207.

[46] Gogoi, P., Thakur, A.J., Devi, R. R., Das B., Maji , T.K. 2016. A Comparative Study on Sorption of Arsenate İons from water by crosslinked chitosan 
and crosslinked chitosan/MMT nanocomposite. Journal of Environmental Chemical Engineering,4, 4248-4257.

[47] Sabaa, M. W., Abdallah, H. M., Mohamed, N. A., Mohamed, R. R. 2015. Synthesis, Characterization and Application of Biodegradable Crosslinked Carboxymethyl Chitosan/Poly(vinyl alcohol) Clay Nanocomposites. Materials Science and Engineering, 56, 363-373.

[48] Yeniova, C. E., Yilmazer, U., 2010. Characteristics of Impact Modified Polystyrene/ Organoclay Nanocomposites. Polymer Composites, 31, 18531861

[49] Çökeliler, D., 2006. Aflatoksin tayini için plazma polimerizasyon yöntemi ile kütle hassas immünosensör hazırlanması. Hacettepe Üniversitesi, Fen Bilimleri Enstitüsü, Doktora Tezi, 205s.

[50] W.R. Bowen, Welfoot, J.S., 2002. Modelling of Membrane Nanofiltration-Pore Size Distribution Effects. Chemical Engineering Science, 57, 13931407.

[51] Gumi, T., Valiente, M., Khulbe, K.C., Palet C., Matsuura, T., 2003. Characterization of Activated Composite Membranes by Solute Transport, Contact Angle Measurement, AFM and ESR. Journal of Membrane Science, 212, 123-134.

[52] Bowen, W. R., Doneva, T.A., 2000. Atomic Force Microscopy Studies of Membranes: Effect of Surface Roughness on Double-Layer Interactions and Particle Adhesion. Journal of Colloid and Interface Science, 229, 544-549.

[53] Tarabara, V.V., Koyuncu, I., Wiesner, M.R., 2004. Effect of Hydrodynamics and Solution Ionic Strength on Permeate Flux in Cross Flow Filtration: Direct Experimental Observation of Filter Cake Cross-Sections. Journal of Membrane Science, 241, 65-78.

[54] Ochoa, N., Pagliero, C., Marchese, J., Mattea M., 2001. Ultrafiltration of Vegetable Oils Degumming by Polymeric Membranes. Separation and Purification Technology, 22-23, 417-422.

[55] Lee, H.T., Lin L.H., 2006. Waterborne Polyurethane/Clay Nanocomposites: Novel Effects of the Clay and its İnterlayer İons on the Morphology and Physical and Electrical Properties. Macromolecules, 39, 6133-6141.

[56] Das, P., Schipmann, S., Malho, J.-M., Zhu, B., Klemradt U., Walther, A., 2013. Facile Access to Large-Scale, Self-Assembled, Nacre-Inspired, High-Performance Materials with Tunable Nanoscale Periodicities. ACS Appl. Mater. Interfaces, 5, 3738-3747.

[57] Matusik, J., Stodolak,E., Bahranowski, K., 2011. Synthesis of Polylactide/Clay Composites Using Structurally Different Kaolinites and Kaolinite nanotubes. Applied Clay Science,51, 102-109.

[58] Darie , R. N., Pâslaru , E., Sdrobis, A., Pricope, G.M., Hitruc, G. E., Poiata, A., Baklavaridis, A., Cornelia ,V., 2014. Effect of Nanoclay Hydrophilicity on the
Poly(lactic acid)/Clay Nanocomposites Properties. Ind. Eng. Chem. Res., 53, 7877-7890. 